\title{
Recent advances and current challenges in allogeneic stem cell transplantation in patients with acquired severe aplastic anemia
}

\author{
Sung-Eun Lee and Jong Wook Lee
}

Department of Hematology, Catholic Blood and Marrow Transplantation Center, Seoul St. Mary's Hospital, College of Medicine, The Catholic University of Korea, Seoul, Republic of Korea

Abstract

Allogeneic stem cell transplantation (SCT) from a human leukocyte antigen (HLA) -matched sibling donor (MSDSCT) is the preferred first-line treatment option for young patients with severe aplastic anemia (SAA). However, only $25 \%$ of patients may find an HLA-MSD. SAA patients, who lack a suitable MSD and fail first-line immunosuppressive therapy, may consider SCT from an unrelated donor (URD-SCT) as a treatment option. The results of haplo-identical stem cell transplantation from a related mismatched donor (Haplo-SCT) have improved due to recent advances in controlling graft failure and graft-versus-host disease (GVHD). The use of Haplo-SCT has recently been extended to SAA patients. However, it is important for physicians to select the appropriate conditioning regimen and GVHD prophylaxis to ensure engraftment with reduced toxicity, such as infectious complications and GVHD.

This review summarizes recent advances in allogeneic SCT for patients with acquired SAA. Current challenges, including the age of the patients and the effects of donor age, stem cell source, and iron overload on transplantation outcomes are also discussed.

Key words: severe aplastic anemia, hematopoietic stem cell transplantation, age, conditioning regimen, iron overload

Submitted March 6, 2018; Accepted May 19, 2018; Published online August 29, 2018; Issued online November 25, 2018

Correspondence: Jong Wook Lee, MD, PhD, Department of Hematology, Catholic Blood and Marrow Transplantation Center, Seoul St. Mary's Hospital, College of Medicine, The Catholic University of Korea, 222 Banpodaero, Seocho-Gu, Seoul 06591, Republic of Korea, E-mail: jwlee@catholic.ac.kr

\section{Introduction}

Aplastic anemia (AA) is an immune-mediated clinical syndrome characterized by fatty replacement and decreased number of hematopoietic precursors in the bone marrow $(\mathrm{BM})$, resulting in peripheral pancytopenia $^{1}$. Allogeneic stem cell transplantation (SCT) from a human leukocyte antigen (HLA)-matched related donor (MSD-SCT) is the preferred first-line treatment option for young patients with severe AA (SAA), whereas immunosuppressive therapy (IST), mainly based on antithymocyte globulin (ATG) with cyclosporine A (CSA), is an alternative option for other patients ${ }^{2}$. However, patients who fail to achieve hematological response after IST are considered for SCT from unrelated donors (URD-SCT) ${ }^{3}$ and other alternative stem cell sources, including unrelated cord blood (CB) or haplo-identical related mismatched donors (Haplo-SCT) ${ }^{4}$.

This review article summarizes recent advances in allogeneic SCT for patients with acquired SAA, with the exception of $\mathrm{CB}$ transplantation. Current challenges, including the age of patients and the effects of donor age, stem cell source, and iron overload on transplantation outcomes are also discussed.

Transplantation from HLA-matched sibling donors

MSD-SCT is an established treatment for young patients with acquired $\mathrm{SAA}^{5-7}$. In a study by the European Group for Blood and Marrow Transplantation (EBMT), failure-free survival (FFS) was compared between patients receiving first-line MSD-SCT and first-line IST $^{8}$. Young patients $(<20$ years $)$ with low neutrophil count benefited from first-line MSD-SCT, whereas patients 
Table 1. Reported outcomes of SAA patients who received MSD-SCT

\begin{tabular}{|c|c|c|c|c|c|c|c|c|}
\hline Study & Study design & $\mathrm{N}$ & $\begin{array}{l}\text { Age, median } \\
\text { (range), yr }\end{array}$ & $\begin{array}{l}\text { Conditioning } \\
\text { regimen }\end{array}$ & $\begin{array}{c}\text { Graft } \\
\text { failure*, \% }\end{array}$ & $\begin{array}{c}\text { Acute } \\
\text { GVHD }^{\dagger}, \%\end{array}$ & $\begin{array}{c}\text { Chronic } \\
\text { GVHD, \% }\end{array}$ & OS, \% \\
\hline \multirow{2}{*}{ Storb et al. $(1994)^{15}$} & \multirow{2}{*}{ Prospective } & 39 & $25(2-46)$ & Cy alone & 8 & 20 & 61 at $3 y r$ & 72 at $3 y r^{*}$ \\
\hline & & 39 & $25(2-52)$ & $\mathrm{Cy}+\mathrm{ATG}$ & 5 & 15 & 34 at $3 y r$ & 92 at $3 y r^{*}$ \\
\hline \multirow{2}{*}{ Ades et al. $(2004)^{5}$} & \multirow{2}{*}{ Retrospective } & 100 & \multirow{2}{*}{ NA } & Cy+TAl & \multirow{2}{*}{ NA } & 42 & 64 at $5 y r$ & 69 at $5 y r$ \\
\hline & & 33 & & $\mathrm{Cy}+\mathrm{ATG}$ & & 0 & 42 at $5 y r$ & 90 at $5 y r$ \\
\hline \multirow{2}{*}{$\begin{array}{l}\text { Champlin et al. } \\
(2007)^{7}\end{array}$} & \multirow{2}{*}{ Prospective } & 60 & $26(4-51)$ & Cy alone & 18 & 18 & 21 at $5 y r$ & 74 at $5 y r$ \\
\hline & & 70 & $23(1-51)$ & $\mathrm{Cy}+\mathrm{ATG}$ & 16 & 11 & 32 at $5 y r$ & 80 at $5 y r$ \\
\hline \multirow{2}{*}{ Maury et al. (2009) ${ }^{16}$} & \multirow{2}{*}{ Registry-based } & 30 & $46(31-66)$ & $\mathrm{Flu}+\mathrm{Cy} \pm \mathrm{ATG}$ & 3 & 10 & 26 & 77 at $5 y r$ \\
\hline & & 239 & $39(30-67)$ & $\mathrm{Cy} \pm \mathrm{ATG}$ & 12 & 19 & 32 & 60 at $5 y r$ \\
\hline Shin et al. $(2016)^{17}$ & Retrospective & 117 & $39(15-63)$ & Flu+Cy+ATG & 13 & 9 & 9 at $5 y r$ & 92 at $5 y r$ \\
\hline
\end{tabular}

GVHD, acute graft-versus-host disease; OS, overall survival; Cy, cyclophosphamide; ATG, anti-thymocyte globulin; TAI, thoraco-abdominal irradiation; NA, not available; Flu, fludarabine.

*Primary and secondary graft failure

${ }^{\dagger}$ Acute GVHD $\geq$ grade 2

over 40 years old with higher neutrophil count did not. Patients with intermediate age (21-40 years old) and average neutrophil count had comparable survival irrespective of the type of first-line therapy. Similar results were observed in an extended group of patients with SAA from the EBMT Registry9.

Regarding the conditioning regimen for SAA patients who receive MSD-SCT, many protocols have been explored for successful engraftment with minimal complications, mainly graft-versus-host disease (GVHD). In an initial attempt of conditioning with cyclophosphamide (Cy) alone, graft failure remained a significant concern, particularly in previously transfused patients ${ }^{10}$. The subsequent addition of radiation to the conditioning regimen resulted in lower rates of graft failure ${ }^{10-13}$; however, these radiation-based regimens were also associated with higher transplantation-related long-term morbidity and mortality ${ }^{12-14}$. Later, several investigators attempted a combination of ATG with $\mathrm{Cy}$, which promoted both excellent engraftment and long-term outcome through adequate lymphoablation. Storb et al. reported excellent outcomes using $\mathrm{Cy}+\mathrm{ATG}$, with $95 \%$ engraftment, $15 \%$ acute GVHD, and 34\% chronic GVHD. Overall survival (OS) rate at three years was $92 \%$ in 39 patients conditioned with Cy + ATG compared with $72 \%$ for 39 historical patients conditioned with Cy alone ${ }^{15}$ (Table 1). In a French retrospective study with 133 patients receiving MSD-SCT with Cy + ATG conditioning or Cy + thoracoabdominal irradiation (TAI), TAI was associated with higher rates of acute and chronic GVHD and lower OS compared to $\mathrm{Cy}+\mathrm{ATG}^{5}$. Based on these results, $\mathrm{Cy}+$ ATG has been widely used as the standard conditioning regimen for MSD-SCT. However, transplantation-related mortality remains high in old patients administered this regimen. Champlin et al. did not find any significantly different outcomes between $\mathrm{Cy}$ alone and $\mathrm{Cy}+\mathrm{ATG}^{7}$. More recently, EBMT examined the role of a fludarabine
(Flu) -containing conditioning regimens ${ }^{16}$. In a retrospective analysis of 30 patients over 30 years old receiving MSD-SCT with a Flu-based conditioning regimen, patients conditioned with Flu had better OS than the standard regimen group $(\mathrm{Cy} \pm \mathrm{ATG})(P=0.04)$ when adjusting for recipient age. This might be due to considerably reduced incidence of primary graft failure in patients receiving Flu ( $0 \%$ vs. $11 \%, P=0.09$ ) (Table 1). These results suggest that a Flu-based conditioning regimen might reduce the negative impact of age in old patients with SAA receiving MSD-SCT ${ }^{16,17}$ (discussed below in Current challenges).

\section{Transplantation from unrelated donors}

For patients with SAA who fail first-line IST or require urgent allogeneic SCT, URD-SCT is considered as an alternative therapy, if there is no suitable MSD. Until the late $1990 \mathrm{~s}, 30-40 \%$ of AA patients who underwent URD-SCT survived long-term ${ }^{3}$, while improved survival rates $(70-80 \%)$ can now be expected through better selection of HLA-matched URD donors due to improved highresolution DNA typing ${ }^{18}$ and modified conditioning regimens ${ }^{19-22}$.

The optimal conditioning regimens of URD-SCT for patients with SAA have been studied. In a study conducted by the EBMT using Flu $\left(120 \mathrm{mg} / \mathrm{m}^{2}\right)+\mathrm{Cy}(1200$ $\left.\mathrm{mg} / \mathrm{m}^{2}\right)+\operatorname{ATG}(7.5 \mathrm{mg} / \mathrm{kg})$ for URD-SCT, the incidence of graft failure was $18 \%$ and the OS rate was $73 \%$ at two years $^{23}$ (Table 2). In this study, patients older than 14 years old showed a significantly higher incidence of graft failure ( $32 \%$ vs. $5 \% ; P=0.030$ ) with a lower trend of OS rate $(61 \%$ vs. $84 \%$ at two years; $P=0.200)$ compared with younger patients. Subsequent EBMT analyses tested a combination of Flu + Cy + ATG with or without lowdose (2 Gy) total body irradiation (TBI) and showed that TBI (2 Gy) for URD-SCT extended the benefit of 
Table 2. Reported outcomes for SAA patients who received URD-SCT

\begin{tabular}{|c|c|c|c|c|c|c|c|c|}
\hline Study & Study design & $N$ & $\begin{array}{l}\text { Age, median } \\
\text { (range), yr }\end{array}$ & $\begin{array}{l}\text { Conditioning } \\
\text { regimen }\end{array}$ & $\begin{array}{c}\text { Graft } \\
\text { failure*, \% }\end{array}$ & $\begin{array}{c}\text { Acute } \\
\text { GVHD }^{\dagger}, \%\end{array}$ & $\begin{array}{l}\text { Chronic } \\
\text { GVHD, \% }\end{array}$ & OS, \% \\
\hline Kojima et al. $(2002)^{67}$ & Registry-based & 154 & $17(1-46)$ & $\begin{array}{l}\text { TBI+Cy } \pm \text { ATG } \\
L F I+C y \pm A T G\end{array}$ & 11 & 29 & 30 & 56 at $5 \mathrm{yr}$ \\
\hline $\begin{array}{l}\text { Bacigalupo et al. } \\
(2005)^{23}\end{array}$ & Registry-based & $38^{\ddagger}$ & $14(3-37)$ & $\mathrm{Flu}+\mathrm{Cy}+\mathrm{ATG}$ & 18 & 11 & 27 & 73 at $2 y r$ \\
\hline Deeg et al. $(2006)^{20}$ & Prospective & 87 & $19(1-53)$ & $\begin{array}{l}\text { Cy+TBI } \pm \text { ATG } \\
\text { (TBI; dose de-esca- } \\
\text { lation) }\end{array}$ & 5 & NA & 43 & 55 at $7 \mathrm{yr}$ \\
\hline \multirow{2}{*}{$\begin{array}{l}\text { Bacigalupo et al. } \\
(2010)^{19}\end{array}$} & \multirow{2}{*}{ Registry-based } & 52 & $13(3-51)$ & $\mathrm{Flu}+\mathrm{Cy}+\mathrm{ATG}$ & 17 & 17 & 23 & 73 at $5 \mathrm{yr}$ \\
\hline & & 48 & $27(7-53)$ & $\mathrm{Flu}+\mathrm{Cy}+\mathrm{ATG}+\mathrm{TBI}$ & 17 & 19 & 38 & 79 at $5 \mathrm{yr}$ \\
\hline Lee et al. $(2011)^{27}$ & Retrospective & 50 & $28(15-53)$ & $\mathrm{Cy}+\mathrm{TBI}$ & 2 & 46 & 50 at $5 \mathrm{yr}$ & 88 at $5 \mathrm{yr}$ \\
\hline \multirow{2}{*}{$\begin{array}{l}\text { Anderlini et al. } \\
(2015)^{24}\end{array}$} & \multirow{2}{*}{ Prospective } & 38 & $24.5(0.5-65.9)$ & $\begin{array}{l}\text { Flu+Cy }(50 \mathrm{mg} / \\
\mathrm{kg})+\mathrm{ATG}+\mathrm{TBI}\end{array}$ & 8 & 24 & 23 at $1 \mathrm{yr}$ & 97 at $1 \mathrm{yr}$ \\
\hline & & 41 & $17.6(1.9-63.3)$ & $\begin{array}{l}\text { Flu+Cy }(100 \mathrm{mg} / \\
\mathrm{kg})+\mathrm{ATG}+\mathrm{TBI}\end{array}$ & 15 & 27 & 32 at $1 \mathrm{yr}$ & 81 at $1 \mathrm{yr}$ \\
\hline \multirow{4}{*}{ Park et al. $(2017)^{30}$} & \multirow{4}{*}{ Retrospective } & \multirow{4}{*}{83} & \multirow{4}{*}{$30(17-59)$} & $\mathrm{Cy}+\mathrm{TBI} \pm \mathrm{ATG}$ & & & & \\
\hline & & & & Group $1^{\S}$ & 0 & 44 & 44 at $3 \mathrm{yr}$ & 84 at $5 \mathrm{yr}$ \\
\hline & & & & Group $2 A^{\S}$ & 1 & 62 & 65 at $3 \mathrm{yr}$ & 92 at $5 \mathrm{yr}$ \\
\hline & & & & Group 2B ${ }^{\S}$ & 0 & 31 & 22 at $3 \mathrm{yr}$ & 88 at $5 \mathrm{yr}$ \\
\hline
\end{tabular}

GVHD, acute graft-versus-host disease; OS, overall survival; EBMT, European Group for Blood and Marrow Transplantation; Flu, fludarabine; Cy, cyclophosphamide; ATG, anti-thymocyte globulin; TBI, total body irradiation; LFI, limited field irradiation.

*Primary and secondary graft failure

${ }^{\dagger}$ Acute GVHD $\geq$ grade 2

₹ 38 SAA patients who underwent SCT from unrelated $(n=33)$ or family mismatched $(n=5)$ donors were enrolled.

The patients were divided into two groups: group $1(n=25)$ received HLA-matched (8/8) bone marrow (BM) without ATG; group 2 ( $n$ $=58$ ) received SCT from either an HLA-mismatched donor or peripheral blood (PB). Thereafter, group 2 was subdivided according to ATG use into group $2 A$ (without $A T G, n=26$ ), which served as a historical cohort, and group 2B (with $A T G, n=32$ ).

transplantation to adult AA patients ${ }^{19}$. However, the relatively high incidence of mortality due to graft failure $(7 \%)$, post-transplantation lymphoproliferative disease $(4 \%)$, and GVHD (4\%) shown in this study remains a challenge. The high proportion of rejections prompted the EBMT group to suggest an increase in the Cy dose to 120 $\mathrm{mg} / \mathrm{kg}$. In contrast, the Seattle group determined the minimal dose of TBI required when added to horse ATG $($ ATGAM, $30 \mathrm{mg} / \mathrm{kg} \times 3)+\mathrm{Cy}(50 \mathrm{mg} / \mathrm{kg} \times 4)$ to achieve engraftment of unrelated donor marrow in 87 patients with $\mathrm{AA}$ who failed to respond to $\mathrm{IST}^{20}$. They found that the optimum TBI dose was $1 \times 200 \mathrm{cGy}$, suggesting that TBI dose de-escalation was effective in reducing transplantation-related toxicity without jeopardizing engraftment. Recently, the Blood and Marrow Transplant Clinical Trials Network (BMT CTN protocol 0301) evaluated different doses of $\mathrm{Cy}(0,50,100$, or 150 $\mathrm{mg} / \mathrm{kg}$ ) combined with a regimen of Flu + ATG + TBI (2 Gy) for URD-SCT in AA patients and identified that Cy $50 \mathrm{mg} / \mathrm{kg}$ was the optimal dose for engraftment and better short-term survival ${ }^{24}$. In a Japanese cohort of $301 \mathrm{AA}$ patients who received URD-SCT using the Japan Marrow Donor Program, the superiority of a Flu $\left(100 \mathrm{mg} / \mathrm{m}^{2}\right)+$ Cy $\left(3000 \mathrm{mg} / \mathrm{m}^{2}\right)+$ ATG $(5$ or $10 \mathrm{mg} / \mathrm{kg})+$ TBI $(3 \mathrm{~Gy})$ regimen over a $\mathrm{Cy}+\mathrm{ATG}+\mathrm{TBI}$ regimen was demonstrated by matched pair analysis ${ }^{25}$.
Early results from a pilot prospective study by Kim et al. to determine a safe and sufficient dose of TBI to be used in combination with $\mathrm{Cy}(120 \mathrm{mg} / \mathrm{kg})$ as a conditioning regimen for URD-SCT in adult patients with SAA demonstrated the superiority of TBI (800 cGy) compared to higher TBI doses (1000 or $1200 \mathrm{cGy})^{26}$. In a subsequent report regarding the long-term outcomes for patients who received URD-SCT using TBI $(800 \mathrm{cGy})+$ Cy $(120 \mathrm{mg} / \mathrm{kg})$ conditioning, all patients achieved sustained myeloid engraftment with acceptable incidence of acute and chronic GVHD (46\% and 50\%, respectively) and a relatively high OS rate ( $88 \%$ at five years) ${ }^{27}$. However, because URD-SCT showed higher incidence of GVHD than MSD-SCT ${ }^{5-7,28,29}$, the incorporation of lowdose ATG $(1.25 \mathrm{mg} / \mathrm{kg} /$ day for two days $)$ into the conditioning regimen for patients with SAA who receive stem cells from either an HLA-mismatched donor or peripheral blood (PB) was tested as a strategy to prevent GVHD $^{30}$. The results demonstrated the beneficial effect of low-dose ATG in reducing the incidence of acute and chronic GVHD and improving the GVHD-free FFS (GFFS) (Table 2).

\section{Alternative donor transplantation: Haplo-SCT}

Use of Haplo-SCT for patients who lack suitable 
Table 3. Reported outcomes for SAA patients who received Haplo-SCT

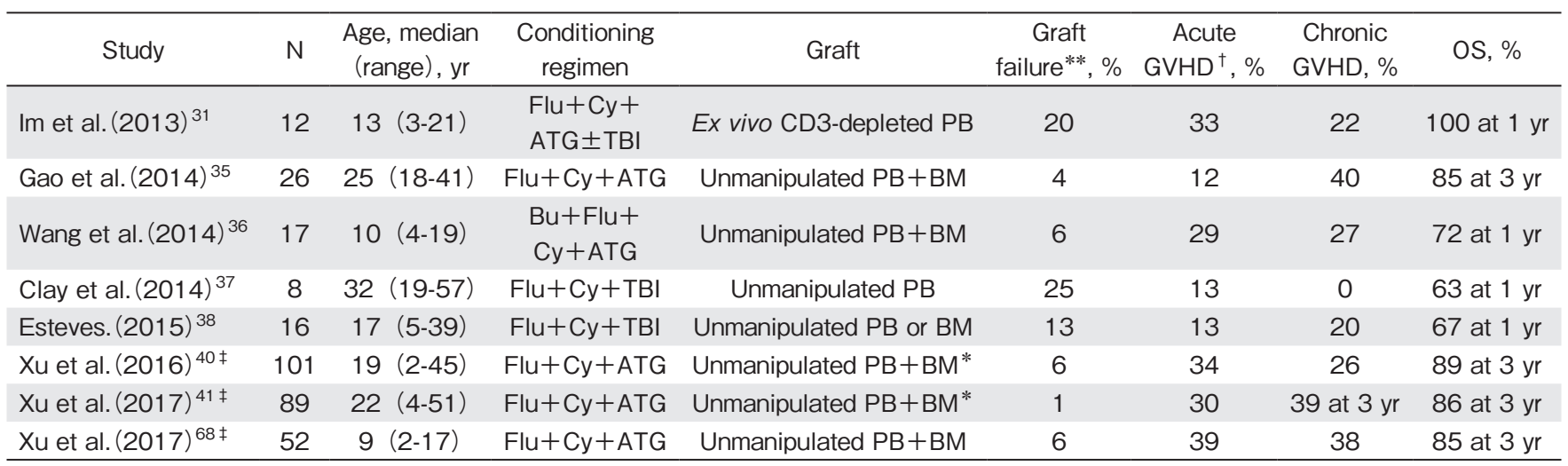

GVHD, acute graft-versus-host disease; OS, overall survival; Flu, fludarabine; Cy, cyclophosphamide; ATG, anti-thymocyte globulin; TBI, Total body irradiation.

* Majority of patients received unmanipulated PB+BM.

** Primary and secondary graft failure

${ }^{\dagger}$ Acute GVHD $\geq$ grade 2

$\ddagger$ Three are different studies in terms of study design and study subjects.

donors is challenging ${ }^{31-33}$. A graft from a related mismatched donor is available for most patients and has the advantages of prompt use and low cost. However, there are no recommendations regarding graft composition and conditioning regimens for Haplo-SCT for SAA patients, due to insufficient data ${ }^{34}$.

Several investigators have explored the optimal conditioning regimens and strategies for graft manipulation for SAA patients who receive Haplo-SCT. An initial retrospective study by the Seattle group showed that patients who received Haplo-SCT using a more intensified conditioning regimen consisting of TBI (1200 cGy) + Cy (120 $\mathrm{mg} / \mathrm{kg}$ ) achieved a higher rate of sustained engraftment (83\% vs. $29 \% ; P<0.050)$ and OS (50.0\% vs. $0 \% ; P<$ $0.050)$ than patients with $\mathrm{Cy}$ conditioning alone $(200 \mathrm{mg} /$ $\mathrm{kg})^{32}$. Tzeng et al. also added TBI ( $\left.800 \mathrm{cGy}\right)$ to Cy (200 $\mathrm{mg} / \mathrm{kg}$ ) to achieve sustained engraftment ${ }^{33}$. Later, Studies from China have shown that a conditioning regimen consisting of $\mathrm{Flu}+\mathrm{Cy}+\mathrm{ATG} \pm$ busulfan $(\mathrm{Bu})$ following unmanipulated PBSC and BM infusion for Haplo-SCT promoted both sustained engraftment and good survival rate $^{35,36}$ (Table 3).

TBI-based conditioning for SAA patients who receive Haplo-SCT was applied in a few studies including a small number of SAA patients ${ }^{37,38}$ (Table 3). Im et al. reported that $3 / 12$ patients receiving Haplo-SCT with T cell-depleted grafts experienced graft failure (GF), including early graft rejection in two patients. In their study, GF occurred in 3/6 patients who did not receive TBI, whereas it did not occur in six patients who received 400 cGy $\mathrm{TBI}^{31}$. Recently, Lee et al. prospectively performed a step-by-step ATG and TBI de-escalation study to determine an optimal conditioning regimen for HaploSCT in SAA patients ${ }^{39}$. They found that $800 \mathrm{cGy}$ TBIbased conditioning with Flu and ATG (10 mg/kg) ensured successful engraftment, while conditioning with TBI $(600 \mathrm{cGy})+$ Flu + ATG $(5 \mathrm{mg} / \mathrm{kg}$, reduced based on the occurrence of transplantation-related mortality [TRM]) also proved sufficient for engraftment with T-cell repleted PBSCs with a two-year OS rate of $91.7 \%$ and two-year GFFS rate of $78.4 \%$.

In a multicenter study from China, conditioning with Cy $(200 \mathrm{mg} / \mathrm{kg})+$ ATG $(2.5 \mathrm{mg} / \mathrm{kg})$ with i.v. Bu (6.4 $\mathrm{mg} / \mathrm{kg}$ ) following G-CSF-primed BM and mobilized PBSC infusion was used for Haplo-SCT ${ }^{40}$. They showed acceptable incidences of acute and chronic GVHD (33.7\% and $25.8 \%$, respectively) and an OS rate of $89 \%$ at three years. They also performed an upfront HaploSCT study using the same conditioning regimen and showed incidences of acute and chronic GVHD of $30.3 \%$ and $39.3 \%$, respectively, and an OS rate of $86.1 \%$ at three years $^{41}$ (Table 3).

In addition, various strategies including use of posttransplant $\mathrm{Cy}$ (PTCy) and selective $\mathrm{CD}^{+}{ }^{+} \mathrm{T}$ cell depletion have been attempted to improve the outcomes of patients who receive Haplo-SCT. DeZern et al. reported that GVHD and graft rejection can be prevented in SAA patients over 40 years old with the addition of PTCy to conventional immunosuppression at days +3 and $+4^{42}$. In contrast, earlier studies on a $\mathrm{T}$ cell-depleted strategy showed that GVHD can be prevented with in vitro CD3 depletion, to remove $\mathrm{T}$ cells, in 12 children and adolescents with SAA who received Haplo-SCT ${ }^{31}$.

Although these limited data suggest that Haplo-SCT might be feasible for SAA patients who lack suitable donors, further research to increase OS by the reduction of GVHD, while maintaining stable engraftment is required in the future. 


\section{Current challenges}

\section{Effect of recipient age}

Current issues for MSD-SCT in AA patients are the upper age limit and optimal conditioning regimens for old patients. The risks of morbidity and mortality arising from SCT increase with age. However, because survival after IST is also associated with lower OS for old patients, the age limit for determining transplantation as first-line treatment is still under debate.

A study by the EBMT/Center for International Blood and Marrow Transplant Research (CIBMTR) with 1307 patients with SAA analyzed the effect of patient age, adjusting for other significant factors that affect outcomes $^{43}$. Neutrophil recovery was similar in all age groups; however, patients over 40 years old showed a lower likelihood of platelet recovery compared to those below 20 years old. The mortality risk was higher for patients over 40 years old (relative risk $[\mathrm{RR}] 2.70, P<$ $0.0001)$ and $20-40$ years old (RR 1.69, $P<0.0001)$ compared to patients below 20 years old. The mortality risk was also higher for patients over 40 years old than patients between 20-40 years old (RR 1.60, $P=0.008$ ). These data showed that mortality risk increased with age. However, several recent studies have attempted reducedintensity conditioning with Flu + attenuated-dose $\mathrm{Cy}+$ ATG to reduce the negative impact of age in old patients with SAA ${ }^{44-47}$. This is supported by the EBMT study, which reported a significantly higher age-adjusted OS rate for patients who received a Flu + attenuated-dose Cy \pm ATG conditioning regimen compared with those who received $\mathrm{Cy} \pm \mathrm{ATG}(P=0.04)$. In addition, there was no significant difference in OS rate between patients 30-39 year old and $\geq 40$ years old in the Flu + attenuated-dose $\mathrm{Cy} \pm$ ATG group $(P=0.30)^{16}$. Recently, Shin et al. analyzed 117 consecutive adult patients with SAA who received MSD-SCT using a Flu + half-dose Cy $(100 \mathrm{mg}$ / $\mathrm{kg})+$ ATG conditioning regimen and showed that the older age group ( $>40$ years) had comparable outcomes to the younger age group ( $\leq 40$ years), with incidences of acute grade II - IV GVHD (9.5\% vs. $9.3 \%$ at day $100 ; P$ $=0.42)$, chronic GVHD ( $8.1 \%$ vs. $9.5 \%$ at five years; $P$ $=0.80)$, secondary graft failure $(20.8 \%$ vs. $7.9 \%$ at five years; $P=0.11)$, FFS rate $(73.7 \%$ vs. $81.0 \%$ at five years; $P=0.73)$, and OS rate $(93.7 \%$ vs. $88.9 \%$ at five years; $P$ $=0.20)^{17}$.

\section{Effect of donor age}

In the registry-based study from Japan, the outcomes of transplantation in patients with SAA who received URD-SCT using BM were compared between younger and older donors. This analysis revealed inferior outcomes for the older donor group, with lower OS for the recipients ${ }^{48}$, consistent with previous reports that showed a positive correlation between donor telomere length and increased survival of SAA patients who had received $\mathrm{SCT}^{49}$. In addition, hematopoietic stem cells from older donors show reduced repopulation efficiency in murine studies $^{50,51}$, and grafts from older donors have a higher ratio of memory-to-naive $\mathrm{T}$ cells ${ }^{52}$, which could in part explain the higher incidence of GVHD with older donors. Therefore, donor age is a consideration when selecting a donor for URD-SCT to improve transplantation outcome.

\section{Stem cell source}

Two registry-based studies have shown that BM transplantation results in a superior outcome compared with PB transplantation in MSD-SCT ${ }^{53,54}$. A combined EBMT/CIBMTR analysis showed a significant survival advantage for young patients $(<20$ years $)$ transplanted with BM but not for older patients $(\geq 20 \text { years })^{54}$. EBMT analysis on a large number of patients $(\mathrm{N}=1886)$, who received MSD-SCT, demonstrated that BM transplantation is superior to PB transplantation due to lower acute and chronic GVHD and a comparable risk of rejection in all age groups ${ }^{53}$. In addition, BM provided a survival advantage in URD-SCT over $\mathrm{PB}^{55,56}$. These evidence indicate that BM should be the standard stem cell source for SCT in SAA patients.

Despite these data, use of PB as a graft source has increased, and some patients unavoidably receive URDSCT using PB due to donor preference. In addition, it is expected that $\mathrm{PB}$ transplantation would overcome the rejection, especially in patients with a heavy transfusion history and high risk of graft failure ${ }^{57}$. Literature from developing countries presents a different aspect for PB grafts $^{57-59}$. Recent pooled analysis from CIBMTR $(\mathrm{n}=$ 1814) and the Japan Society for Hematopoietic Cell Transplantation $(n=560)$ examined the differences in outcomes in different economic regions using $\mathrm{BM}$ or $\mathrm{PB}$ as graft sources, and found no significant difference in OS between these two sources in middle- and lowincome countries ${ }^{60}$. Therefore, although BM should definitely be the preferred graft source for MSD-SCT in SAA patients, PBSC may be an acceptable alternative in countries with limited resources when treating patients at high risk of graft failure and infectious complications.

\section{Iron overload}

Many patients with AA unavoidably receive blood transfusions as supportive care. Regular transfusions of packed red cells (PRCs) leads to iron overload, which increases the risk of TRM and other complications including fungal infections, hepatic dysfunction, and hepatic veno-occlusive disease after $\mathrm{SCT}^{61-64}$. Recently, Lee et al. evaluated the prognostic impact of pre-transplantation PRC transfusion history on the transplantation outcome in SAA patients who had not receive proper iron 

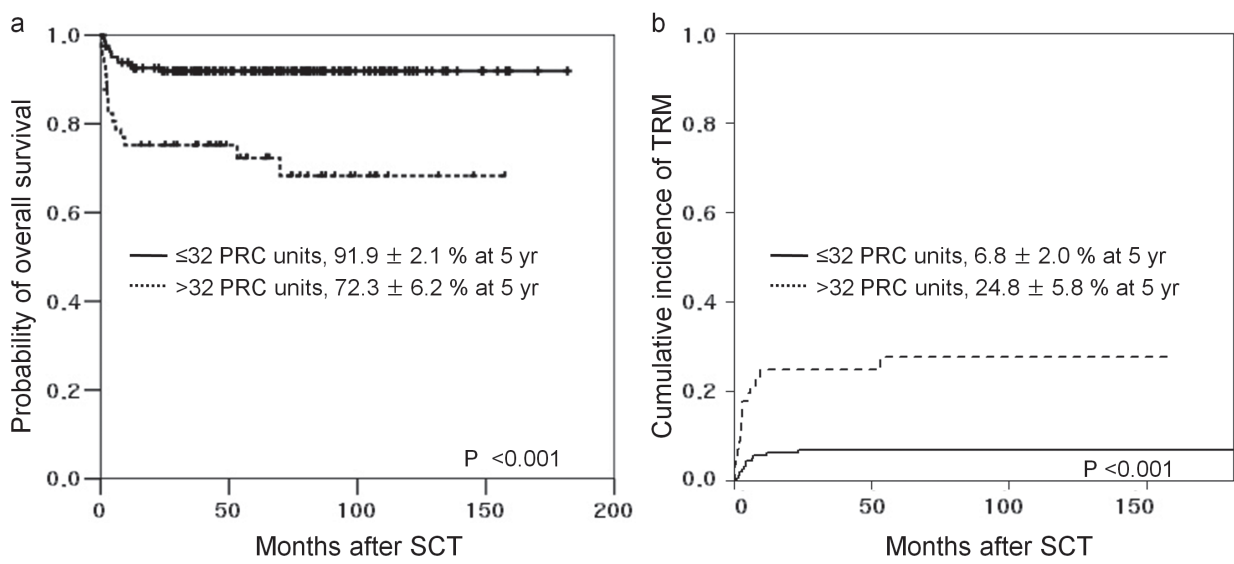

Figure 1. Kaplan-Meier estimates of overall survival (OS) (a) and transplant-related mortality (TRM) (b) according to pretransplant transfusion ( $\leq 32$ PRC units vs. $>32$ PRC units). Solid line, $\leq 32$ PRC units; dashed line, $>32$ PRC units.

Adapted from Lee et al. PRC, packed red blood cells.

chelation therapy (ICT) prior to $\mathrm{SCT}^{65}$. The authors found that a history of higher pre-transplantation PRC transfusion was associated with increased TRM and decreased OS, suggesting that iron overload had a negative impact on the SCT outcome in SAA patients (Figure 1). However, in the pre-deferasirox era, intensive ICT was not widely used for the treatment of patients with iron overload because of poor compliance with deferoxamine treatment. Deferasirox is now available as an oral chelating agent, and further studies examining whether intensive ICT for patients with iron overload will improve the transplantation outcomes are warranted. Notably, most patients, who plan to undergo URD-SCT, were transfusion-dependent after failed IST. For these patients, pretransplantation intensive ICT would be expected to improve transplantation outcomes ${ }^{66}$.

\section{Conclusions}

As MSD-SCT leads to long-term survival, it has become the standard first-line treatment for younger patients with SAA. However, whether MSD-SCT or IST is the best first-line treatment option for older patients remains a current topic of debate. The results of URDSCT have recently been improved by the use of a reduced intensity conditioning regimen and better donor selection; therefore, URD-SCT can now be considered in young patients who failed first-line IST or as a front-line therapy for patients requiring urgent allogeneic SCT, if there is no suitable MSD. Haplo-SCT and other novel approaches are being pursued with substantial progress. Larger prospective studies are required to address currently unresolved questions regarding treatment of patients with SAA.

\section{Authors' Contribution}

JWL and S-EL wrote this manuscript.

\section{Conflict of Interest}

The authors declare no conflict of interest. Disclosure forms provided by the authors are available here.

\section{References}

1. Shin SH, Lee JW. The optimal immunosuppressive therapy for aplastic anemia. International journal of hematology. 2013; 97: 564-72.

2. Marsh JC, Ball SE, Cavenagh J, Darbyshire P, Dokal I, GordonSmith EC, et al. Guidelines for the diagnosis and management of aplastic anaemia. British journal of haematology. 2009; 147: 43-70.

3. Passweg JR, Perez WS, Eapen M, Camitta BM, Gluckman E, Hinterberger W, et al. Bone marrow transplants from mismatched related and unrelated donors for severe aplastic anemia. Bone marrow transplantation. 2006; 37: 641-9.

4. Bacigalupo A. How I treat acquired aplastic anemia. Blood. 2017; 129: 1428-36.

5. Ades L, Mary JY, Robin M, Ferry C, Porcher R, Esperou H, et al. Long-term outcome after bone marrow transplantation for severe aplastic anemia. Blood. 2004; 103: 2490-7.

6. Kahl C, Leisenring W, Deeg HJ, Chauncey TR, Flowers ME, Martin PJ, et al. Cyclophosphamide and antithymocyte globulin as a conditioning regimen for allogeneic marrow transplantation in patients with aplastic anaemia: a long-term follow-up. British journal of haematology. 2005; 130: 747-51.

7. Champlin RE, Perez WS, Passweg JR, Klein JP, Camitta BM, Gluckman E, et al. Bone marrow transplantation for severe aplastic anemia: a randomized controlled study of conditioning 
regimens. Blood. 2007; 109: 4582-5.

8. Bacigalupo A, Brand R, Oneto R, Bruno B, Socie G, Passweg J, et al. Treatment of acquired severe aplastic anemia: bone marrow transplantation compared with immunosuppressive therapy--The European Group for Blood and Marrow Transplantation experience. Seminars in hematology. 2000; 37: 69-80.

9. Bacigalupo A, Giammarco S, Sica S. Bone marrow transplantation versus immunosuppressive therapy in patients with acquired severe aplastic anemia. International journal of hematology. 2016; 104: 168-74.

10. McCann SR, Bacigalupo A, Gluckman E, Hinterberger W, Hows J, Ljungman P, et al. Graft rejection and second bone marrow transplants for acquired aplastic anaemia: a report from the Aplastic Anaemia Working Party of the European Bone Marrow Transplant Group. Bone marrow transplantation. 1994; 13: $233-7$.

11. Gale RP, Ho W, Feig S, Champlin R, Tesler A, Arenson E, et al. Prevention of graft rejection following bone marrow transplantation. Blood. 1981; 57: 9-12.

12. Champlin RE, Horowitz MM, van Bekkum DW, Camitta BM, Elfenbein GE, Gale RP, et al. Graft failure following bone marrow transplantation for severe aplastic anemia: risk factors and treatment results. Blood. 1989; 73: 606-13.

13. Gluckman E, Horowitz MM, Champlin RE, Hows JM, Bacigalupo A, Biggs JC, et al. Bone marrow transplantation for severe aplastic anemia: influence of conditioning and graft-versushost disease prophylaxis regimens on outcome. Blood. 1992; 79: 269-75.

14. Deeg HJ, Socie G, Schoch G, Henry-Amar M, Witherspoon RP, Devergie A, et al. Malignancies after marrow transplantation for aplastic anemia and fanconi anemia: a joint Seattle and Paris analysis of results in 700 patients. Blood. 1996; 87: 38692.

15. Storb R, Etzioni R, Anasetti C, Appelbaum FR, Buckner CD, Bensinger W, et al. Cyclophosphamide combined with antithymocyte globulin in preparation for allogeneic marrow transplants in patients with aplastic anemia. Blood. 1994; 84: 941-9.

16. Maury S, Bacigalupo A, Anderlini P, Aljurf M, Marsh J, Socie $\mathrm{G}$, et al. Improved outcome of patients older than 30 years receiving HLA-identical sibling hematopoietic stem cell transplantation for severe acquired aplastic anemia using fludarabine-based conditioning: a comparison with conventional conditioning regimen. Haematologica. 2009; 94: 1312-5.

17. Shin SH, Jeon YW, Yoon JH, Yahng SA, Lee SE, Cho BS, et al. Comparable outcomes between younger (40 years) and older $(>40$ years) adult patients with severe aplastic anemia after HLA-matched sibling stem cell transplantation using fludarabine-based conditioning. Bone marrow transplantation. 2016; 51: 1456-63.

18. Maury S, Balere-Appert ML, Chir Z, Boiron JM, Galambrun C, Yakouben K, et al. Unrelated stem cell transplantation for severe acquired aplastic anemia: improved outcome in the era of high-resolution HLA matching between donor and recipient. Haematologica. 2007; 92: 589-96.
19. Bacigalupo A, Socie G, Lanino E, Prete A, Locatelli F, Locasciulli A, et al. Fludarabine, cyclophosphamide, antithymocyte globulin, with or without low dose total body irradiation, for alternative donor transplants, in acquired severe aplastic anemia: a retrospective study from the EBMT-SAA Working Party. Haematologica. 2010; 95: 976-82.

20. Deeg HJ, O’Donnell M, Tolar J, Agarwal R, Harris RE, Feig SA, et al. Optimization of conditioning for marrow transplantation from unrelated donors for patients with aplastic anemia after failure of immunosuppressive therapy. Blood. 2006; 108: 148591.

21. Viollier R, Socie G, Tichelli A, Bacigalupo A, Korthof ET, Marsh J, et al. Recent improvement in outcome of unrelated donor transplantation for aplastic anemia. Bone marrow transplantation. 2008; 41: 45-50.

22. Bacigalupo A, Marsh JC. Unrelated donor search and unrelated donor transplantation in the adult aplastic anaemia patient aged 18-40 years without an HLA-identical sibling and failing immunosuppression. Bone marrow transplantation. 2013; 48: 198-200.

23. Bacigalupo A, Locatelli F, Lanino E, Marsh J, Socie G, Maury $\mathrm{S}$, et al. Fludarabine, cyclophosphamide and anti-thymocyte globulin for alternative donor transplants in acquired severe aplastic anemia: a report from the EBMT-SAA Working Party. Bone marrow transplantation. 2005; 36: 947-50.

24. Anderlini P, Wu J, Gersten I, Ewell M, Tolar J, Antin JH, et al. Cyclophosphamide conditioning in patients with severe aplastic anaemia given unrelated marrow transplantation: a phase 1-2 dose de-escalation study. The Lancet Haematology. 2015; 2: e367-75.

25. Kojima S, Nakao S, Young N, Bacigalupo A, Gerard G, Hirano $\mathrm{N}$, et al. The Third Consensus Conference on the treatment of aplastic anemia. International journal of hematology. 2011; 93: 832-7.

26. Kim SY, Lee JW, Lim J, Cho BS, Eom KS, Kim YJ, et al. Unrelated donor bone marrow transplants for severe aplastic anemia with conditioning using total body irradiation and cyclophosphamide. Biology of blood and marrow transplantation: journal of the American Society for Blood and Marrow Transplantation. 2007; 13: 863-70.

27. Lee JW, Cho BS, Lee SE, Eom KS, Kim YJ, Kim HJ, et al. The Outcome of Unrelated Hematopoietic Stem Cell Transplants with Total Body Irradiation ( $800 \mathrm{cGy}$ ) and Cyclophosphamide $(120 \mathrm{mg} / \mathrm{kg})$ in Adult Patients with Acquired Severe Aplastic Anemia. Biology of blood and marrow transplantation: journal of the American Society for Blood and Marrow Transplantation. 2011; 17: 101-8.

28. Locatelli F, Bruno B, Zecca M, Van-Lint MT, McCann S, Arcese W, et al. Cyclosporin A and short-term methotrexate versus cyclosporin A as graft versus host disease prophylaxis in patients with severe aplastic anemia given allogeneic bone marrow transplantation from an HLA-identical sibling: results of a GITMO/EBMT randomized trial. Blood. 2000; 96: 16907. 
29. Kim HJ, Park CY, Park YH, Kim YJ, Kim DW, Min WS, et al. Successful allogeneic hematopoietic stem cell transplantation using triple agent immunosuppression in severe aplastic anemia patients. Bone marrow transplantation. 2003; 31: 79-86.

30. Park SS, Kwak DH, Jeon YW, Yoon JH, Lee SE, Cho BS, et al. Beneficial Role of Low-Dose Antithymocyte Globulin in Unrelated Stem Cell Transplantation for Adult Patients with Acquired Severe Aplastic Anemia: Reduction of Graft-versusHost Disease and Improvement of Graft-versus-Host DiseaseFree, Failure-Free Survival Rate. Biology of blood and marrow transplantation: journal of the American Society for Blood and Marrow Transplantation. 2017; 23: 1498-508.

31. Im HJ, Koh KN, Choi ES, Jang S, Kwon SW, Park CJ, et al. Excellent outcome of haploidentical hematopoietic stem cell transplantation in children and adolescents with acquired severe aplastic anemia. Biology of blood and marrow transplantation: journal of the American Society for Blood and Marrow Transplantation. 2013; 19: 754-9.

32. Wagner JL, Deeg HJ, Seidel K, Anasetti C, Doney K, Sanders J, et al. Bone marrow transplantation for severe aplastic anemia from genotypically HLA-nonidentical relatives. An update of the Seattle experience. Transplantation. 1996; 61: 54-61.

33. Tzeng CH, Chen PM, Fan S, Liu JH, Chiou TJ, Hsieh RK. CY/ TBI-800 as a pretransplant regimen for allogeneic bone marrow transplantation for severe aplastic anemia using HLA-haploidentical family donors. Bone marrow transplantation. 1996; 18: $273-7$.

34. Ciceri F, Lupo-Stanghellini MT, Korthof ET. Haploidentical transplantation in patients with acquired aplastic anemia. Bone marrow transplantation. 2013; 48: 183-5.

35. Gao L, Li Y, Zhang Y, Chen X, Gao L, Zhang C, et al. Longterm outcome of HLA-haploidentical hematopoietic SCT without in vitro T-cell depletion for adult severe aplastic anemia after modified conditioning and supportive therapy. Bone marrow transplantation. 2014; 49: 519-24.

36. Wang Z, Zheng X, Yan H, Li D, Wang H. Good outcome of haploidentical hematopoietic SCT as a salvage therapy in children and adolescents with acquired severe aplastic anemia. Bone marrow transplantation. 2014; 49: 1481-5.

37. Clay J, Kulasekararaj AG, Potter V, Grimaldi F, McLornan D, Raj K, et al. Nonmyeloablative peripheral blood haploidentical stem cell transplantation for refractory severe aplastic anemia. Biology of blood and marrow transplantation: journal of the American Society for Blood and Marrow Transplantation. 2014; 20: 1711-6.

38. Esteves I, Bonfim C, Pasquini R, Funke V, Pereira NF, Rocha V, et al. Haploidentical BMT and post-transplant $\mathrm{Cy}$ for severe aplastic anemia: a multicenter retrospective study. Bone marrow transplantation. 2015; 50: 685-9.

39. Lee S-E, Park SS, Jeon Y-W, Yoon J-H, Cho B-S, Eom K-S, et al. Optimal Conditioning Regimen for Haplo-Identical Stem Cell Transplantation in Adult Patients with Acquired Severe Aplastic Anemia: Prospective De-Escalation Study of TBI and ATG Dose. Blood. 2016; 128: 2196.
40. Xu LP, Wang SQ, Wu DP, Wang JM, Gao SJ, Jiang M, et al. Haplo-identical transplantation for acquired severe aplastic anaemia in a multicentre prospective study. British journal of haematology. 2016; 175: 265-74.

41. Xu LP, Jin S, Wang SQ, Xia LH, Bai H, Gao SJ, et al. Upfront haploidentical transplant for acquired severe aplastic anemia: registry-based comparison with matched related transplant. Journal of hematology \& oncology. 2017; 10: 25.

42. Dezern AE, Luznik L, Fuchs EJ, Jones RJ, Brodsky RA. Posttransplantation cyclophosphamide for GVHD prophylaxis in severe aplastic anemia. Bone marrow transplantation. 2011; 46: 1012-3.

43. Gupta V, Eapen M, Brazauskas R, Carreras J, Aljurf M, Gale $\mathrm{RP}$, et al. Impact of age on outcomes after bone marrow transplantation for acquired aplastic anemia using HLA-matched sibling donors. Haematologica. 2010; 95: 2119-25.

44. Resnick IB, Aker M, Shapira MY, Tsirigotis PD, Bitan M, Abdul-Hai A, et al. Allogeneic stem cell transplantation for severe acquired aplastic anaemia using a fludarabine-based preparative regimen. British journal of haematology. 2006; 133: 649-54.

45. George B, Mathews V, Viswabandya A, Kavitha ML, Srivastava A, Chandy M. Fludarabine and cyclophosphamide based reduced intensity conditioning (RIC) regimens reduce rejection and improve outcome in Indian patients undergoing allogeneic stem cell transplantation for severe aplastic anemia. Bone marrow transplantation. 2007; 40: 13-8.

46. Kim H, Lee JH, Joo YD, Bae SH, Hyun MS, Lee JH, et al. A randomized comparison of cyclophosphamide vs. reduced dose cyclophosphamide plus fludarabine for allogeneic hematopoietic cell transplantation in patients with aplastic anemia and hypoplastic myelodysplastic syndrome. Annals of hematology. 2012; 91: 1459-69.

47. Srinivasan R, Takahashi Y, McCoy JP, Espinoza-Delgado I, Dorrance C, Igarashi $\mathrm{T}$, et al. Overcoming graft rejection in heavily transfused and allo-immunised patients with bone marrow failure syndromes using fludarabine-based haematopoietic cell transplantation. British journal of haematology. 2006; 133: 305-14.

48. Arai Y, Kondo T, Yamazaki H, Takenaka K, Sugita J, Kobayashi $\mathrm{T}$, et al. Allogeneic unrelated bone marrow transplantation from older donors results in worse prognosis in recipients with aplastic anemia. Haematologica. 2016; 101: 644-52.

49. Gadalla SM, Wang T, Haagenson M, Spellman SR, Lee SJ, Williams KM, et al. Association between donor leukocyte telomere length and survival after unrelated allogeneic hematopoietic cell transplantation for severe aplastic anemia. Jama. 2015; 313: 594-602.

50. Liang Y, Van Zant G, Szilvassy SJ. Effects of aging on the homing and engraftment of murine hematopoietic stem and progenitor cells. Blood. 2005; 106: 1479-87.

51. Kamminga LM, van Os R, Ausema A, Noach EJ, Weersing E, Dontje B, et al. Impaired hematopoietic stem cell functioning after serial transplantation and during normal aging. Stem cells 
(Dayton, Ohio). 2005; 23: 82-92.

52. Miller RA. The aging immune system: primer and prospectus. Science（New York, NY). 1996; 273: 70-4.

53. Bacigalupo A, Socie G, Schrezenmeier H, Tichelli A, Locasciulli A, Fuehrer M, et al. Bone marrow versus peripheral blood as the stem cell source for sibling transplants in acquired aplastic anemia: survival advantage for bone marrow in all age groups. Haematologica. 2012; 97: 1142-8.

54. Schrezenmeier H, Passweg JR, Marsh JC, Bacigalupo A, Bredeson CN, Bullorsky E, et al. Worse outcome and more chronic GVHD with peripheral blood progenitor cells than bone marrow in HLA-matched sibling donor transplants for young patients with severe acquired aplastic anemia. Blood. 2007; 110: 1397-400.

55. Bacigalupo A, Socie G, Hamladji RM, Aljurf M, Maschan A, Kyrcz-Krzemien S, et al. Current outcome of HLA identical sibling versus unrelated donor transplants in severe aplastic anemia: an EBMT analysis. Haematologica. 2015; 100: 696702.

56. Eapen M, Le Rademacher J, Antin JH, Champlin RE, Carreras J, Fay J, et al. Effect of stem cell source on outcomes after unrelated donor transplantation in severe aplastic anemia. Blood. 2011; 118: 2618-21.

57. Seth T, Kanga U, Sood P, Sharma V, Mishra P, Mahapatra M. Audit of peripheral stem cell transplantation for aplastic anemia in multitransfused infected patients. Transplantation proceedings. 2012; 44: 922-4.

58. Kumar R, Prem S, Mahapatra M, Seth T, Chowdhary DR, Mishra P, et al. Fludarabine, cyclophosphamide and horse antithymocyte globulin conditioning regimen for allogeneic peripheral blood stem cell transplantation performed in nonHEPA filter rooms for multiply transfused patients with severe aplastic anemia. Bone marrow transplantation. 2006; 37: 7459.

59. George B, Mathews V, Viswabandya A, Srivastava A, Chandy M. Fludarabine-based reduced intensity conditioning regimens for allogeneic hematopoietic stem cell transplantation in patients with aplastic anemia and fungal infections. Clinical transplantation. 2009; 23: 228-32.

60. Kumar R, Kimura F, Ahn KW, Hu ZH, Kuwatsuka Y, Klein JP, et al. Comparing Outcomes with Bone Marrow or Peripheral
Blood Stem Cells as Graft Source for Matched Sibling Transplants in Severe Aplastic Anemia across Different Economic Regions. Biology of blood and marrow transplantation: journal of the American Society for Blood and Marrow Transplantation. 2016; 22: 932-40.

61. Pullarkat V, Blanchard S, Tegtmeier B, Dagis A, Patane K, Ito J, et al. Iron overload adversely affects outcome of allogeneic hematopoietic cell transplantation. Bone marrow transplantation. 2008; 42: 799-805.

62. Altes A, Remacha AF, Sureda A, Martino R, Briones J, Canals $\mathrm{C}$, et al. Iron overload might increase transplant-related mortality in haematopoietic stem cell transplantation. Bone marrow transplantation. 2002; 29: 987-9.

63. Strasser SI, Kowdley KV, Sale GE, McDonald GB. Iron overload in bone marrow transplant recipients. Bone marrow transplantation. 1998; 22: 167-73.

64. Lichtman SM, Attivissimo L, Goldman IS, Schuster MW, Buchbinder A. Secondary hemochromatosis as a long-term complication of the treatment of hematologic malignancies. American journal of hematology. 1999; 61: 262-4.

65. Lee SE, Yahng SA, Cho BS, Eom KS, Kim YJ, Kim HJ, et al. Impact of pretransplant red cell transfusion on outcome after allogeneic stem cell transplantation in adult patients with severe aplastic anemia. Bone marrow transplantation. 2016; 51: 1323-9.

66. Lee JW, Kang HJ, Kim EK, Kim H, Shin HY, Ahn HS. Effect of iron overload and iron-chelating therapy on allogeneic hematopoietic SCT in children. Bone marrow transplantation. 2009; 44: 793-7.

67. Kojima S, Matsuyama T, Kato S, Kigasawa H, Kobayashi R, Kikuta A, et al. Outcome of 154 patients with severe aplastic anemia who received transplants from unrelated donors: the Japan Marrow Donor Program. Blood. 2002; 100: 799-803.

68. Xu LP, Zhang XH, Wang FR, Mo XD, Han TT, Han W, et al. Haploidentical transplantation for pediatric patients with acquired severe aplastic anemia. Bone marrow transplantation. 2017; 52: 381-7.

https://doi.org/10.31547/bct-2018-001 Copyright @ 2018 APBMT. All Rights Reserved. 